\title{
Genetic divergence among accessions of Arachis repens based on vegetative morphological traits
}

\section{José Marlo Araújo de Azevedo ${ }^{1}$, Hellen Sandra Freires da Silva ${ }^{2}$, Giselle Mariano Lessa de Assis $^{3}$, Laís Fernanda Andrade dos Santos ${ }^{2}$, Priscila Ferreira Wolter ${ }^{2}$}

\footnotetext{
1 Produção Vegetal da UFAC, BR 364, km 4, CP 500, Rio Branco, AC, 69915-900.

2 Ciências Biológicas da UNINORTE, BR 364, km 2, Rio Branco, AC, 69911-900.

${ }^{3}$ Embrapa Acre, Rodovia BR 364, km 14, CP 321, Rio Branco, AC, 69908-970.
}

\begin{abstract}
The objective of this study was to verify the existence of genetic variability among accessions of Arachis repens based on vegetative morphological characters, identifying those which contribute least for distinction of those accessions. Nineteen accessions were evaluated in a completely randomized design with ten replicates, established in $4-\mathrm{m}^{2}$ plots. The traits evaluated were: basal leaflet length, basal leaflet width, apical leaflet length, apical leaflet width, petiole length, internode average length and internode diameter. The data obtained were submitted to univariate statistical analysis and accessions were grouped by the Scott-Knott test, at $1 \%$ of probability. The analysis of canonical variables and Tocher method were used to study the genetic divergence among accessions. Six heterogeneous groups were formed by Tocher method and eight groups were formed by technique of canonical variables, in which a consistency among grouping set by the different techniques used was observed. There is genetic divergence among accessions of $A$. repens on the basis of vegetative morphology traits, but there is the need to extend variability in Banco Ativo de Germoplasma de Amendoim Forrageiro (Active Germplasm Bank of Forage Peanut). Apical leaflet length is the trait that contributes least to the accessions' distinctions, but it is important to maintain the standard cluster, and it should not be discarded.
\end{abstract}

Key Words: forage Peanut, genetic improvement, multivariate analysis

\section{Introduction}

Most economically important tropical forages have high genetic variability, which can be explored in the selection of new cultivars with desirable characteristics. Among the forage legumes of Arachis genus, Arachis pintoi Krapovickas \& Gregory and Arachis repens Handro species are the most promising for utilization as forage in the South American tropics and are found in Section Caulorrhizae (Assis \& Valentim, 2009). Both are perennial, with low and stoloniferous growth, with quadrifoliolate leaves, rather extended branches and adventitious roots at the nodes (Rodrigues et al., 2006). Collecting expeditions were intensively carried out in the 1980s and continue until the present, resulting in a collection of about 150 accessions of Caulorrhizae section (Valls, 2001).

Peanut-forage feed is recommended for animal feeding in South, Central and North America and Australia. Because they are perennial and present morphological features that confer better adaptation to grazing, trampling and harvest, and based on records of the use by herbivores in their original environment, the species $A$. pintoi, $A$. repens and $A$. glabrata are the most collected and evaluated when it comes to forage yield (Valls \& Simpson, 1994; Valls \& Pizarro, 1994).

Studies on morphological characteristics of plants are important because they enable access to the existing variability among genotypes of the germplasm bank, besides being useful as an auxiliary tool in genetic improvement programs (Veiga et al., 1996). In plant breeding programs, knowledge of diversity and genetic diversity within a species is essential for the rational use of genetic resources (Loarce et al., 1996). In the study of genetic diversity, there are various statistical methods, whose choice is based on the accuracy desired by the researcher, ease of analysis and the manner in which the data were obtained (Rodrigues et al., 2006). Multivariate analysis techniques can be used to evaluate the difference between accessions and to select the most important descriptors for discrimination of accessions of a germplasm bank (Pereira et al., 1992; Amaral Júnior et al., 1994).

This study was carried out with the following objectives: to verify the existence of genetic variability 
among accessions of Arachis repens; to study the genetic diversity based on vegetative morphological traits and to identify traits that contribute least to the discrimination of accessions, and that therefore can be discarded.

\section{Material and Methods}

The study was conducted from data obtained in the Banco Ativo de Germoplasma de Amendoim Forrageiro located at Embrapa Acre, in Rio Branco (AC) (9॰58 ' 22 "S latitude, $67^{\circ} 48$ ' 40 " W longitude and altitude of $160 \mathrm{~m}$ ). The average annual temperature in the region is $24.3^{\circ} \mathrm{C}$ with relative humidity of $84 \%$, average annual rainfall of $1,860 \mathrm{~mm}$, with rainy season from October to April and dry season from June to September (BRASIL, 2009).

Nineteen accessions of $A$. repens (Table 1) from Banco Ativo de Germoplasma de Amendoim Forrageiro, located at Embrapa Acre were evaluated. This bank was established in 2006 from the accessions from Active Germplasm Bank of Arachis, located at Embrapa Recursos Genéticos e Biotecnologia, in Brasília, Distrito Federal.

The design was completely randomized with ten replicates, in Red-Yellow Latosol with medium texture. Chemical analysis of soil from the collection cultivated area presented the following characteristics: phosphorus = $3 \mathrm{mg} / \mathrm{dm}^{3} ;$ potassium $=0.3 \mathrm{cmol}_{\mathrm{c}} / \mathrm{dm}^{3}$; potassium $=3.4$ $\mathrm{cmol}_{\mathrm{c}} / \mathrm{dm}^{3}$; calcium + magnesium $=0.7 \mathrm{cmol}_{\mathrm{c}} / \mathrm{dm}^{3}$; exchangeable aluminum $=3.62 \mathrm{cmol}_{C} / \mathrm{dm}^{3}$; aluminum + hydrogen $=15.9 \%$ of aluminum saturation, and $\mathrm{pH}=5.0$.

Table 1 - Identification, BRA code and collection site of 19 accessions of Arachis repens from Banco Ativo de Germoplasma de Amendoim Forrageiro located at Embrapa Acre

\begin{tabular}{ccc}
\hline Access identification & BRA code & Collection site \\
\hline 1 & 033260 & Sertanópolis - PR \\
2 & 029220 & Januária - MG \\
3 & 032352 & Buenópolis - MG \\
4 & 034436 & Itauçu - GO \\
5 & 032379 & Buenópolis - MG \\
6 & 032387 & Joaquim Felício - MG \\
7 & 032280 & Itacarambi - MG \\
8 & 012106 & Alpestre - RS \\
9 & 029190 & Buenópolis - MG \\
10 & 029203 & Vitória - ES \\
11 & 012114 & São Gabriel - RS \\
12 & 040088 & Ribeirão Cascalheira - MT \\
13 & 037443 & Brasília - DF \\
14 & 014788 & Várzea da Palma - MG \\
15 & 014770 & Várzea da Palma - MG \\
16 & 032361 & Buenópolis - MG \\
17 & 040185 & Caraguatatuba - SP \\
18 & 034363 & Mineiros - GO \\
19 & 032492 & Boa Vista - RR \\
\hline
\end{tabular}

Four-square-meter plots for each access ionfrom the vegetative propagation, with the use of $20-30 \mathrm{~cm}$ runners were established. Two runners were placed in each hole, with $0.5 \mathrm{~m} \times 0.5 \mathrm{~m}$ spacing. The area was fertilized with $50 \mathrm{~kg} / \mathrm{ha} \mathrm{P}_{2} \mathrm{O}_{5}$ (triple superphosphate), $40 \mathrm{~kg} / \mathrm{ha} \mathrm{K}_{2} \mathrm{O}$ (potassium chloride) and $40 \mathrm{~kg} / \mathrm{ha}$ of FTE BR12. For morphological characteristic measurement, ten runners were collected from each plot.

The following morphological characteristics were evaluated: basal leaflet length (BLL), basal leaflet width (BLW), apical leaflet length (ALL), apical leaflet width (ALW), petiole length (PEL), internode average length (IAL) and internode average diameter (IAD). All these characteristics were measured in millimeters, by using a digital caliper. Basal leaflet length, basal leaflet width, apical leaflet length, apical leaflet width and petiole length were determined in the fourth leaf on apex-base direction by using runners with at least $30 \mathrm{~cm}$ in length, with at least seven internodes. The characteristics internode average length and internode average diameter were obtained by collecting the distal portion of runners, with at least seven internodes. The three distal internodes were discarded, and the length between the internodes 3-4, 4-5, 5-6 and 6-7 and the diameter of the internodes 3, 4, 5 and 6 in the apex-base direction in each one of the ten runners were measured. The choice of features and manners of obtaining them were based on the study of Paganella \& Valls (2002), Maass et al. (1993), Monçato (1995) and Charvalho \& Quesenberry (2008).

Data were submitted to univariate statistical analysis, accessions were grouped by Scott-Knott test (1974) 1\% probability. Additionally, Pearson's correlation was estimated among traits. The study of genetic diversity was performed by multivariate analysis techniques, which employed the canonical variable analysis (Cruz et al., 2004) and the optimization method of Tocher (RAO, 1952). The dissimilarity measure used in the cluster analysis was the Mahalanobis generalized distance $\left(\mathrm{D}^{2}\right)$. Statistical analysis was performed using the GENES software (Cruz, 2006).

\section{Results and Discussion}

Coefficients of experimental variation obtained were from medium to low magnitude and, in general, higher than those verified by Monçato (1995) for A. repens (Table 2). However, considering the common characteristics evaluated, the traits with the greatest coefficient of experimental variation were the same in both studies (petiole length and average length of runners). The same 
trend was observed by Maass et al. (1993) in a study on morphological characterization of A. pintoi.

The relationship between the coefficients of genetic and experimental variation was higher than the unit for length of the basal leaflets, length of apical leaflet, apical width of leaves, internode average length and average diameter, which reflects a very favorable situation for the selection, inasmuch as the coefficient of genetic variation expresses, as a percentage of the overall mean, the amount of genetic variation among genotypes. Knowledge of this coefficient is important in a genetic improvement program because it indicates the amplitude of genetic variation in a variable, regarding the possibility of its improvement (Assis et al., 2009).

Monçato (1995) studied morphological characterization of 51 accessions of Caulorrhizae section and noted that only ten belonged to A. repens. The mean values of the characteristics listed below presented by Monçato (1995) for $A$. repens were very close to those found in this study (Table 2): internode average length $=31.22 \mathrm{~mm}$; thickness of runners $=2.4 \mathrm{~mm}$, petiole length $=9.7 \mathrm{~mm}$; apical leaflets length $=18.3 \mathrm{~mm}$, apical leaflets width $=8.9 \mathrm{~mm}$; basal leaflets length $=16.7 \mathrm{~mm}$; basal leaflets width $=7.1 \mathrm{~mm}$. From the 19 accessions of $A$. repens characterized in this study, only five are common to the study performed by Monçato (1995).

Carvalho \& Quesenberry (2008) characterized morphologically 34 accessions of A. pintoi for 44 morphological traits, including leaves, runners, flowers, fruit and seeds. The authors found that among the traits evaluated in the leaves, the shape, length, width of the leaflets and petiole length were the traits that most presented variability among the accessions studied.

In the Scott-Knott test, the results of basal leaflet length of the accessions were divided into five groups, so accessions BRA 032379 and BRA 034363 were the ones which presented greatest mean for this trait (Table 3). For basal leaflet width, four groups were established: accessions BRA 032387 and 034363 BRA were allocated in the first group, with leaves presenting larger leaflets; and accession

Table 2 - Mean, minimum, maximum, standard deviation (SD), genotypic variance (Vg), coefficient of genetic variation (CGV) and coefficient of experimental variation (CVe) of the characteristics measured in 19 accessions of Arachis repens from the Banco Ativo de Germoplasma located at Embrapa Acre

\begin{tabular}{|c|c|c|c|c|c|c|c|}
\hline Trait & Mean & Minimum & Maximum & Standard deviation & Genotipic variation & $\mathrm{CVg}$ & CVe \\
\hline Basal leaflet length (mm) & 16.43 & 12.40 & 22.28 & 2.93 & $8.06 * *$ & 17.28 & 13.54 \\
\hline Basal leaflet width (mm) & 7.77 & 5.72 & 10.61 & 1.28 & $1.50 * *$ & 15.76 & 16.27 \\
\hline Apical leaflet length (mm) & 17.88 & 13.74 & 24.69 & 3.28 & $10.30 * *$ & 17.95 & 12.40 \\
\hline Apical leaflet width (mm) & 9.25 & 6.91 & 14.91 & 2.01 & $3.76 * *$ & 20.96 & 17.69 \\
\hline Petiole length (mm) & 11.79 & 6.50 & 18.86 & 2.23 & $13.43 * *$ & 31.07 & 33.31 \\
\hline Internode average length (mm) & 32.27 & 19.95 & 54.30 & 8.66 & $71.42 * *$ & 26.19 & 18.73 \\
\hline Internode average diameter (mm) & 1.98 & 1.13 & 2.48 & 0.32 & $0.10 * *$ & 15.94 & 9.59 \\
\hline
\end{tabular}

** For $1 \%$ of probability by $\mathrm{F}$ test.

Table 3 - Means of 19 accessions of Arachis repens evaluated for morphological traits

\begin{tabular}{|c|c|c|c|c|c|c|c|}
\hline $\begin{array}{l}\text { Access } \\
\text { (BRA) }\end{array}$ & $\begin{array}{l}\text { Basal leaflet } \\
\text { length }(\mathrm{mm})\end{array}$ & $\begin{array}{l}\text { Basal leaflet } \\
\text { width (mm) }\end{array}$ & $\begin{array}{l}\text { Apical leaflet } \\
\text { length }(\mathrm{mm})\end{array}$ & $\begin{array}{l}\text { Apical leaflet } \\
\text { width }(\mathrm{mm})\end{array}$ & $\begin{array}{l}\text { Internode } \\
\text { length }(\mathrm{mm})\end{array}$ & $\begin{array}{l}\text { Average internode } \\
\text { length }(\mathrm{mm})\end{array}$ & $\begin{array}{c}\text { Average internode } \\
\text { diameter (mm) }\end{array}$ \\
\hline 033260 & $15.75 d$ & $6.73 c$ & $17.19 \mathrm{c}$ & $7.47 \mathrm{~d}$ & $13.14 b$ & $22.54 \mathrm{e}$ & $1.79 \mathrm{~d}$ \\
\hline 029220 & $14.80 \mathrm{~d}$ & $6.15 \mathrm{~d}$ & $15.41 \mathrm{~d}$ & $6.91 d$ & $17.22 \mathrm{a}$ & $19.95 \mathrm{e}$ & $1.13 \mathrm{f}$ \\
\hline 032352 & $20.40 \mathrm{~b}$ & 8.69b & $20.90 b$ & $953 c$ & $12.91 b$ & $40.08 b$ & $2.05 c$ \\
\hline 034436 & $15.94 d$ & $8.48 b$ & $17.16 \mathrm{c}$ & 8.59d & $9.72 c$ & $36.84 c$ & $2.28 \mathrm{~b}$ \\
\hline 032379 & $22.28 \mathrm{a}$ & $9.04 \mathrm{~b}$ & $24.15 a$ & $12.20 \mathrm{~b}$ & $15.73 a$ & $34.99 c$ & $2.19 \mathrm{c}$ \\
\hline 032387 & $16.12 \mathrm{~d}$ & $9.57 \mathrm{a}$ & $18.19 \mathrm{c}$ & 11.91b & $7.65 c$ & $33.06 \mathrm{c}$ & $2.47 \mathrm{a}$ \\
\hline 032280 & $15.86 \mathrm{~d}$ & $8.41 b$ & $17.62 \mathrm{c}$ & $9.70 \mathrm{c}$ & $8.43 c$ & $32.34 c$ & $2.09 c$ \\
\hline 012106 & $17.75 c$ & $7.66 \mathrm{c}$ & $20.02 b$ & $9.79 c$ & $13.44 b$ & $31.32 d$ & $1.87 \mathrm{~d}$ \\
\hline 029190 & 19.95b & $9.00 \mathrm{~b}$ & $20.57 b$ & $10.22 \mathrm{c}$ & $18.85 a$ & $20.13 \mathrm{e}$ & $1.60 \mathrm{e}$ \\
\hline 029203 & $16.71 \mathrm{~d}$ & $6.95 c$ & $18.38 \mathrm{c}$ & 8.61d & $13.75 b$ & $28.38 d$ & $2.08 \mathrm{c}$ \\
\hline 012114 & $14.49 \mathrm{~d}$ & $6.86 \mathrm{c}$ & $13.90 \mathrm{~d}$ & $7.56 \mathrm{~d}$ & $8.16 \mathrm{c}$ & $25.95 d$ & $1.84 \mathrm{~d}$ \\
\hline 040088 & $14.80 \mathrm{~d}$ & $7.10 \mathrm{c}$ & $16.76 \mathrm{c}$ & $7.78 \mathrm{~d}$ & $9.85 c$ & $30.83 d$ & $1.92 \mathrm{~d}$ \\
\hline 037443 & $13.16 \mathrm{e}$ & $6.34 d$ & $14.76 \mathrm{~d}$ & 7.99d & $8.70 \mathrm{c}$ & $35.14 c$ & $1.71 \mathrm{e}$ \\
\hline 014788 & $14.75 d$ & $7.44 \mathrm{c}$ & $16.56 \mathrm{c}$ & $8.60 \mathrm{~d}$ & $10.08 \mathrm{c}$ & $41.62 b$ & $2.06 \mathrm{c}$ \\
\hline 014770 & $12.40 \mathrm{e}$ & $6.62 c$ & $13.74 d$ & $7.94 d$ & 8.13c & $35.20 c$ & $1.74 \mathrm{e}$ \\
\hline 032361 & $14.05 \mathrm{e}$ & $8.28 b$ & $14.64 d$ & 9.31c & $8.32 \mathrm{c}$ & $21.30 \mathrm{e}$ & $1.96 \mathrm{c}$ \\
\hline 040185 & $13.06 \mathrm{e}$ & $5.72 d$ & $14.08 \mathrm{~d}$ & $7.04 \mathrm{~d}$ & $6.50 \mathrm{c}$ & $27.82 \mathrm{~d}$ & $2.02 \mathrm{c}$ \\
\hline 034363 & $21.92 \mathrm{a}$ & $10.61 \mathrm{a}$ & $24.69 a$ & $14.90 \mathrm{a}$ & $16.62 \mathrm{a}$ & $54.29 \mathrm{a}$ & $2.47 \mathrm{a}$ \\
\hline 032492 & $18.07 \mathrm{c}$ & 7.99b & $20.94 b$ & $9.72 c$ & $16.91 \mathrm{a}$ & $41.24 b$ & $2.33 \mathrm{~b}$ \\
\hline
\end{tabular}

Means followed by the same letter within the column belong to the same cluster by Scott-Knott test t $1 \%$ of probability. 
BRA 037443 was in the last group, with narrower leaflets. For the characteristic length of apical leaflet, four groups were formed, and accessions BRA 032379 and BRA 034363 were those which presented greatest means for this trait. In relation to the width of apical leaflet, four groups were formed: only accession BRA 034363 in the first group with the greatest mean, and accessions BRA 033260, BRA 029220, BRA 012114, BRA BRA 040088 and BRA 040185 in the last group, with narrower apical leaflet. For petiole length, three groups were established, in which accession BRA 029220, BRA 032379, BRA 029190, BRA 034363 and BRA 032492 were in the first group with the greatest means. Regarding the average length of internode, there was formation of five groups, in which accession BRA 034363 was allocated in the group with greatest mean. For average diameter of the internode, five groups were established, with accession BRA 032387 and BRA 034363 in the first group with the greatest means, and accession BRA 029220 was the only one in the sixth group with the lowest mean.

Accession BRA 034363 differed from other genotypes in many characteristics, evidencing its high genetic distance in relation to the others, as also observed in the study of genetic diversity, which will be discussed later. This accession was collected in a public square in Mineiros, GO and therefore already in culture condition, with unknown natural occurrence site. It is important to say that $A$. repens is a native species and it is exclusive in the Brazilian flora, and that accession 032379 BRA equated BRA 034363 for the characteristic length of the basal leaflets, length of apical leaflet and petiole length.

The most strongly correlated variables were length of basal leaflet and apical leaflet length, basal leaflet width and apical leaflet width and apical leaflet length with apical leaflet width (Table 4). The result of this study corroborates that observed by Balzon et al. (2006) when studying genetic diversity in accessions and hybrids of Arachis spp. According to the authors, the traits related to leaf size (BLL, BLW, ALL, ALW and PL) were all strongly correlated.
Correlations between traits observed in experimental trials are due to genetic and environmental factors (Vencovsky \& Barriga, 1992) and are estimated to measure the variation in a trait when it modifies another. In this study, plants with longer leaflets also had longer petioles, but this relationship was not observed in relation to the width of the leaflets. The characteristics related to the dimensions of the leaflets, such as length and width were strongly correlated, but not strongly related to traits in runners.

According to the results reported by Carvalho \& Quesenberry (2009), who estimated the Pearson correlations for morphological traits in A. pintoi, the values obtained between length and width of leaflets (0.79), length of leaflet and petiole length (0.76), internode diameter and width of leaflets (0.56) were similar to those found in this study to A. repens. However, in A. repens, the correlations between width of leaflets and petiole length were of low magnitude and not significant, whereas for A. pintoi (Carvalho \& Quesenberry, 2009) these estimates were of high magnitude (0.77). In the study by Carvalho \& Quesenberry (2009), there was no correlation between length and diameter of internodes in A. pintoi, whereas for A. repens that estimate was from medium to high magnitude and significant (Table 4). These correlations indicate that selection of genotypes with long and wide leaflets with short internodes and thin runners, which could result in plants with high leaf:stem relation, may be impaired in A. repens. The study of genetic diversity, which will be presented later, confirms this result because only one accession (BRA 029190) out of the 19 evaluated met all these attributes.

The formation of clusters by Scott-Knott test allows the grouping of genotypes based only on one characteristic at a time (univariate analysis), requiring a multivariate analysis when studying the genetic divergence based on various characteristics simultaneously. Studies found in literature usually refer to genetic diversity in A. pintoi or consider the two species simultaneously, which stresses

Table 4 - Phenotypic correlations between morphological characteristics of accessions of Arachis repens from the Banco Ativo de Germoplasma de Amendoim Forrageiro located at Embrapa Acre

\begin{tabular}{|c|c|c|c|c|c|c|c|}
\hline & BLL & BLW & ALL & ALW & PEL & IAL & IAD \\
\hline BLL & 1 & $0.7599 * *$ & $0.9692 * *$ & $0.7747 * *$ & $0.7286 * *$ & $0.3958 \mathrm{~ns}$ & $0.3845 \mathrm{~ns}$ \\
\hline BLW & - & 1 & $0.7645^{* *}$ & $0.9167 * *$ & $0.3275 \mathrm{~ns}$ & $0.4873 *$ & $0.6356 * *$ \\
\hline ALL & - & - & 1 & $0.8232 * *$ & $0.7081 * *$ & $0.5101 *$ & $0.4838 *$ \\
\hline PEL & - & - & - & - & 1 & $0.0593 \mathrm{~ns}$ & $-0.153 n s$ \\
\hline IAL & - & - & - & - & - & 1 & $0.677 * *$ \\
\hline IAD & - & - & - & - & - & - & 1 \\
\hline
\end{tabular}

ns - non-significant; * and ** significant at $5 \%$ and $1 \%$ of probability by t test, respectively.

$\mathrm{BLL}$ = basal leaflet lenght; BLW = basal leaflet width; ALL = apical leaflet lenght; ALW = apical leaflet width; PEL = petiole lenght; IAL = internode average lenght; $\mathrm{IAD}=$ internode average diameter. 
the need to understand the variability and genetic diversity found within the species $A$. repens.

The cluster analysis by the Tocher optimization method, based on Mahalanobis generalized distance, formed six heterotic groups (Table 5). The first group, consisting of 12 accessions, is characterized by having access with small basal and apical leaflets, with short petioles, medium to short internodes and thick medium to short runners. The second group, consisting of three accessions, differed from the first due to its larger and wider leaflets and longer petioles. The other groups were all formed by only one accession each one because they had unique characteristics, as follows: the third group, formed by BRA 032379 (accession 6), presents short leaflets, but wider and thicker runners; in the fourth group formed by BRA 029190 (accession 9), the leaflets are medium to large in size, petioles are long, but internodes are short and runners are thin; the fifth group, formed by BRA 029220 (accession 2), has small leaflets, long petioles, short internodes and thin runners; and the sixth group, formed by BRA 034363 (accession 18), is characterized by the presence of longer and wider leaflets, long petiole, larger internodes and thicker runners.

The formation of these clusters is important for choosing the parents, inasmuch as the new hybrid combinations to be established must be based on the magnitude of their dissimilarities. The accessions assembled in more distant groups give an indication of being dissimilar, and they can be considered as promising in artificial crosses. However, in addition to being dissimilar, it is necessary that parents associate high mean and variability for the traits which are being improved, and additional studies on agronomic and chemical evaluation of these genotypes be done. Assessments of this kind were reported by Assis et al. (2010), who identified two accessions of A. repens (BRA 029190 and BRA 012106) with desirable agronomic traits such as rapid ground cover and high dry matter production during the establishment.

In the technique of canonical variables, the feasibility of its interpretation is restricted to the concentration of the variability available among the first variables, usually above $80 \%$ (Cruz et al., 2004). The two first variables explained $71.6 \%$ of total variation ( $47.1 \%$ by the first and $24.5 \%$ by the second) ( Table 6). Because the two first canonical variables did not reach the $80 \%$ of the total variation, the third variable was included in this study, and that was sufficient to explain $84.9 \%$ of the total variation, considering the first three variables in the study of graphic dispersion (Figure 1). Accessions BRA 029220 (2), BRA032379 (5), BRA032387 (6), BRA 029190 (9) and BRA 034363 (18) were divergent among each other and in relation to other groups formed. As in the Tocher method, a large group was formed in canonical variable analysis, but without the presence of BRA037443 (13), BRA014788 (14) and BRA 014770 (15). Accession BRA032379 (5), which formed the isolated group by the technique of canonical variables was similar to accessions BRA032352 (3) and ARB 032492 (19) by the Tocher method.

The distribution of accession in the formation of the clusters was similar in both techniques of genetic diversity

Table 5 - Cluster analysis by the Tocher optimization method, obtained through the generalized Mahalanobis distances (D²) of 19 accessions of Arachis repens from Banco Ativo de Germoplasma de Amendoim Forrageiro at Embrapa Acre

\begin{tabular}{|c|c|c|c|c|c|c|c|c|c|c|c|c|}
\hline Cluster & & & & & & Acces & & & & & & \\
\hline 1 & 13 & 15 & 11 & 12 & 17 & 14 & 01 & 16 & 07 & 10 & 04 & 08 \\
\hline 2 & 03 & 19 & 05 & & & & & & & & & \\
\hline 3 & 09 & & & & & & & & & & & \\
\hline 5 & 18 & & & & & & & & & & & \\
\hline 6 & 02 & & & & & & & & & & & \\
\hline
\end{tabular}

Table 6 - Accumulated variance and weighing coefficients associated with the canonical variables ( VC $_{\mathrm{i}}$ ) established by vegetative morphological traits

\begin{tabular}{lcrrrrrrr}
\hline & Cumulative variance (\%) & BLL & BLW & ALL & ALW & PEL & IAL & IAD \\
\hline $\mathrm{VC}_{1}$ & 47.1 & 0.04 & 0.10 & 0.18 & 0.22 & 0.13 & 0.46 & 0.53 \\
$\mathrm{VC}_{2}$ & 71.6 & -0.22 & 0.16 & -0.52 & -0.03 & -0.31 & -0.28 & 0.72 \\
$\mathrm{VC}_{3}$ & 84.9 & -0.32 & -0.15 & -0.19 & -0.11 & 0.26 & 0.91 & -0.28 \\
$\mathrm{VC}_{4}$ & 92.9 & -0.16 & 0.62 & -0.42 & $0.75^{\dagger}$ & -0.22 & 0.13 & -0.51 \\
$\mathrm{VC}_{5}$ & 96.7 & $-1.19^{\dagger}$ & 0.03 & 0.32 & 0.31 & 0.90 & -0.17 & 0.25 \\
$\mathrm{VC}_{6}$ & 98.6 & -0.47 & -0.62 & $0.83^{\dagger}$ & 0.46 & -0.55 & -0.13 & -0.17 \\
$\mathrm{VC}_{7}$ & 100 & -1.06 & 0.77 & $1.32^{\dagger}$ & -0.70 & -0.39 & -0.02 & -0.24 \\
\hline
\end{tabular}

† Lower importance traits for divergence among genotypes, according to results of canonical variable analysis.

$\mathrm{BLL}$ = basal leaflet lenght; BLW = basal leaflet width; ALL = apical leaflet lenght; ALW = apical leaflet width; PEL = petiole lenght; IAL = internode average lenght; $\mathrm{IAD}=$ internode average diameter. 


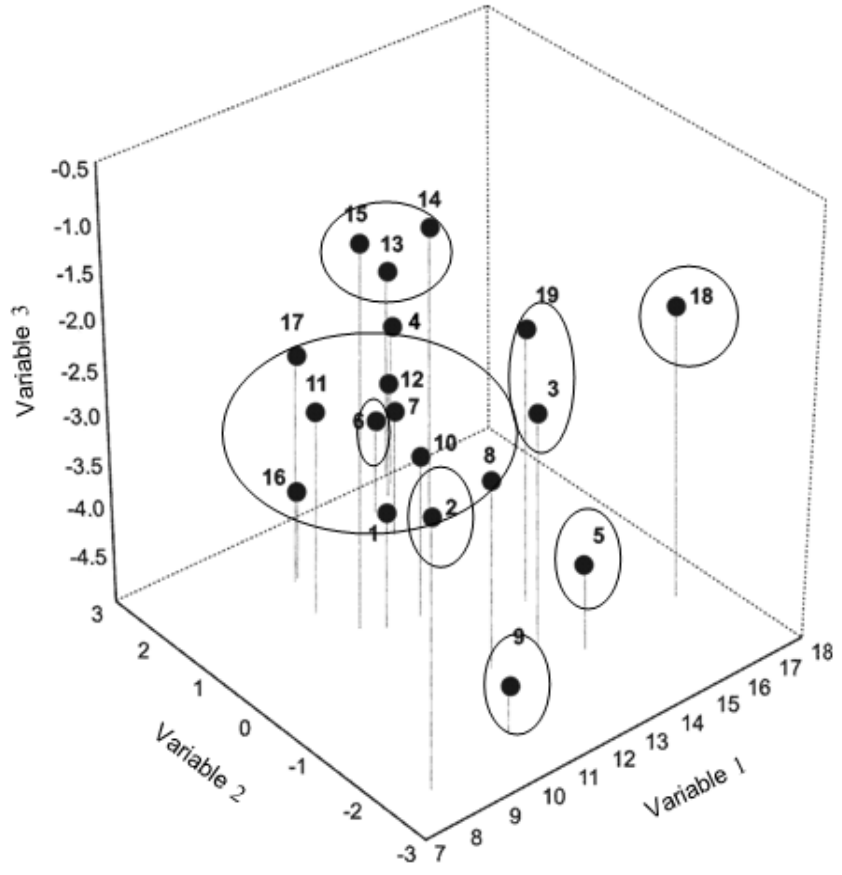

Figure 1 - Graph dispersion of 19 accessions of Arachis repens belonging to the Banco Ativo de Germoplasma de amendoim forrageiro located at Embrapa Acre, obtained by canonical variable analysis.

used. Similar results were observed by Benin et al. (2002), who worked with the identification of genetic dissimilarity among genotypes of bean (Phaseolus vulgaris L.). These authors also used the methods of Tocher, nearest neighbor and canonical variables and found that, although the genotypes were grouped in a similar way, some differed in relation to the technique used. The use of different multivariate analysis techniques is commonly followed by many authors to verify if there is no consistency among the clusters obtained. Furthermore, the use of different techniques is strategic for obtaining complementary results, as it occures with the Tocher method, which generates clustering and canonical variables that, besides the formation of clusters, can identify traits which contribute less in the analysis of genetic divergence.

To assess the relative importance of traits in the genetic divergence, in the last canonical variable, those whose weighing coefficients were of greater magnitude in absolute value were classified as the least important (Cruz et al., 2004) (Table 6). The least important traits were, in order of disposal, apical leaflet length, basal leaflet length and apical leaflet width.

The possibility of discarding traits which contributes least to discrimination of evaluated genetic material is important, because it reduces labor, time and cost spent in the experimentation (Cruz et al., 2004). However, Cruz et al. (2004) recommended to carry out a new cluster analysis by the Tocher method, not considering the least important variable to confirm its low contribution in discriminating accessions. In this study, when the least relative important trait (length of apical leaflet) identified by the method of canonical variables was discarded, the number of clusters established by the method of Tocher optimization decreased from six to four and the position of accessions in cluster was also modified. Therefore, by this criterion, it is not recommended to discard this variable, because all traits contributed to the clustering pattern obtained in the study of genetic diversity among accessions. A similar result was found by Shimoya et al. (2002) in the study of genetic divergence among accessions of a germplasm bank of elephant grass (Pennisetum purpureum, Schum.). According to the authors, when the trait with least relative importance, which was stem diameter, was discarded, by the method of canonical variables, the number of clusters established by the Tocher method increased from 18 to 19 , and the position of the genotypes was also changed.

\section{Conclusions}

There is genetic variability among Arachis repens for vegetative morphology traits, but the study of genetic diversity demonstrates the need for extending this variability by collecting or introducing new accession into Active Germplasm Bank of Peanut Forage. The genetic similarity observed among accessions belonging to different clusters can guide the breeder in the definition of crosses to be made in the breeding programs, where crossings among accessions allocated in the same cluster should be avoided. Accession BRA 029190 introduces vegetative morphological and agronomic traits for use as forage, being recommended as a parent in genetic improvement programs. The length of apical leaflet is the trait that contributes least to the dissimilarity among accessions of Arachis repens, but it should not be discarded in order to maintain the standard clustering of the accessions.

\section{Acknowledgments}

Thanks to Dr. Rui Carlos Peruquetti, for collaborating in formatting the figures. Thanks to UNIPASTO for financially supporting the project. 


\section{References}

AMARAL JÚNIOR, A.T.; CASALI, V.W.D.; ALFENAS, A.C. et al. Análise isozimática de acessos de moranga (Cucurbita maxima Duchesne). Horticultura Brasileira, v.12, n.1, p.37-39, 1994.

ASSIS, G.M.L.; VALENTIM, J.F. Forage peanut breeding program in Brazil. In: SIMPÓSIO INTERNACIONAL SOBRE MELHORAMENTO DE FORRAGEIRAS, 2., 2009, Campo Grande. Anais... Campo Grande: Embrapa Gado de Corte, 2009. (CD-ROM).

ASSIS, G.M.L.; VALENTIM, J.F.; MENEZES, A.P.M. et al. Seleção de genótipos de amendoim forrageiro durante o período de estabelecimento no Acre. In: REUNIÃO ANUAL DA SOCIEDADE BRASILEIRA DE ZOOTECNIA, 47., 2010, Salvador. Anais... Salvador: UFBA; SBZ, 2010. (CD-ROM).

BALZON, T.A.; ASSIS, G.M.L.; VALENTIM, J.F. et al. Divergência genética de acessos e híbridos de Arachis spp. baseada em caracteres morfológicos. In: REUNIÃO ANUAL DA SOCIEDADE BRASILEIRA DE ZOOTECNIA, 43., 2006, João Pessoa. Produção animal em biomas tropicais. Anais... Brasília: SBZ, 2006. (CD-ROM).

BENIN, G.; CARVALHO, F.I.F.; ASMANN, I.C. et al. Identificação da dissimilaridade genética entre genótipos de feijoeiro comum (Phaseolus vulgaris L.) do grupo preto. Revista Brasileira de Agrociência, v.8, n.3, p.179-184, 2002.

BRASIL. Ministério da Agricultura Pecuária e Abastecimento. Agritempo. Sistema de Monitoramento Agrometereológico: dados metereológicos: Acre. [Campinas]: Embrapa Informática Agropecuária, 2009. Available at: <http://www.agritempo.gov.br. modules.php?name=Mapas\&estado=AC $>$. Accessed on: Oct. 9, 2010.

CARVAlHO, M.A.; QUESENBERRY, K.H. Morphological characterization of the USA Arachis pintoi Krap. and Greg. Collection. London: Springer-Verlag, 2008.

CARVALHO, M.A.; QUESENBERRY, K.H. Morphological characterization of the USA Arachis pintoi Krap. and Greg. Collection. Plant Systematics and Evolution, v.277, p.1-11, 2009.

CRUZ, C.D. Programa Genes: análise multivariada e simulação. Viçosa, MG: Editora UFV, 2006. 175p.

CRUZ, C.D.; REGAZZI, A.J.; CARNEIRO, P.C.S. Modelos biométricos aplicados ao melhoramento genético. 3.ed. Viçosa, MG: Universidade Federal de Viçosa, 2004. 480p.

LOARCE, Y.; GALLEGO, R.; FERRER, E.A. comparative analysis of the genetic relationship between rye cultivars using RFLP and RAPD markers. Euphytica, v.88, p.107-115, 1996.
MAASS, B.L.; TORRES, A.M.; OCAMPO, C.H. Morphological and sozyme characterization of Arachis pintoi Krap. et Greg. nom. nud. ermplasm. Euphytica, v.70, p.43-52, 1993.

MONÇATO, L. Caracterização morfológica de germoplasma de espécies de Arachis, secção Caulorrhizae, pela análise multivariada. 1995. 122f. Dissertação (Mestrado em Genética) - Universidade Estadual Paulista, Botucatu.

PAGANELLA, M.B.; VALLS, F.J.M. Caracterização morfológica de cultivares e acessos selecionados de Arachis pintoi Krapov. \& Gregory. Pasturas Tropicales, v.24, n.2, p.22-29, 2002.

PEREIRA, A.V.; VENCOVSKY, R.; CRUZ, C.D. Selection of botanical and agronomical descriptors for the characterization of cassava (Manihot esculenta Crantz) germoplasm. Revista Brasileira de Genética, v.5, n.1, p.115-124, 1992.

RAO, R.C. Advanced statistical methods in biometric. New York: John Wiley and Sons, 1952. 352p.

RODRIGUES, A.A.C.; SILVA, G.S.; MORAES, F.H.R. et al. Arachis repens: novo hospedeiro de Puccinia arachidis. Fitopatologia Brasileira, v.31, n.4, p.411, 2006.

SHIMOYA, A.; CRUZ, C.D.; FERREIRA, R.P. et al. Divergência genética entre acessos de um banco de germoplasma de capimelefante. Pesquisa Agropecuária Brasileira, v.32, n.7, p.971-980, 2002.

SCOTT, A.J.; KNOTT, M.A Cluster analysis method for grouping means in the analysis of variance. Biometrics, v.30, p.507-512, 1974.

VALLS, J.F.M. Situação atual da coleta e utilização de germoplasma de espécies silvestres de Arachis In: SIMPÓSIO DE RECURSOS GENÉTICOS PARA A AMÉRICA LATINA E CARIBE, 3., 2001, Londrina. Anais... Londrina: IAPAR, 2001. p.105-108.

VALLS, J.F.M.; PIZARRO, E.A. Collection of wild Arachis. In: KERRIDGE, P.C.; HARDY, B. (Orgs.). Biology and agronomy of forage Arachis. Cali: CIAT, 1994. p.19-27.

VALLS, J.F.M.; SIMPSON, C.E. Taxonomy, natural distribution, and attributes of Arachis. In: KERRIDGE, P.C.; HARDY, B. (Eds.). Biology and agronomy of forage Arachis. Cali: CIAT, 1994. p.18.

VEIGA, R.F.A.; NAGAI, V.; GODOY, I.J. et al. Caracterização morfológica de acessos de amendoim: avaliação da sensibilidade de alguns descritores. Bragantia, v.55, n.1, p.45-56, 1996.

VENCOVSKY, R.; BARRIGA, P. Associação entre caracteres. In: Genética biométrica no fitomelhoramento. Ribeirão Preto: Sociedade Brasileira de Genética, 1992. p.335-434.

VENCOVSKY, R.; BARRIGA, P. Genética biométrica no fitomelhoramento. Ribeirão Preto: Sociedade Brasileira de Genética, 1992. 496p. 